\title{
Isolasi, Identifikasi, dan Uji Antibakteri Kitosan Cangkang Bekicot (Achatina fulica) Terhadap Staphylococcus aureus dari Penderita Ulkus Diabetikum
}

\section{Isolation, Identification, and Antibacterial Test Of Gastropod Shell Chitosan (Achatina fulica. Against Staphylococcus aureus From Diabetic Ulcer}

\author{
Umarudin $^{1} *$ dan Surahmaida ${ }^{2}$ \\ ${ }^{12}$ Akademi Farmasi Surabaya. JL. Ketintang madya No 81 Surabaya \\ *Koresponden: umarsains54@ gmail.com
}

\begin{abstract}
Abstrak
Salah satu bakteri penyebab ulkus diabetikum adalah Staphylococcus aureus. Pengunaan antibiotik yang tidak tepat menyebabkan munculnya $S$. aureus yang resisten terhadap antibiotik atau bertahan hidup karena adanya perubahan genetic. Bahan alam yang memiliki sifat sebagai antibakteri adalah kitosan cangkang bekicot.Penelitian ini bertujuan untuk melakukan isolasi dan uji antibakteri kitosan cangkang bekicot terhadap Staphylococcus aureus dari penderita ulkus diabetikum dan juga dilakukan uji sensitifitas S. aureus terhadap kitosan cangkang bekicot. Pada penelitian inidilakukan secara true eksperimental. S. aureus diisolasi dari penderita ulkus diabetikum dan diidentifikasi berdasarkan sifat biakan, pewarnaan Gram, uji biokimiawi dan uji gula-gula. Isolat selanjutnya diuji sensitifitasnya terhadap kitosan cangkang bekicot. Hasil penelitian menunjukkan bahwa isolasi bakteri yang tumbuh dan dapat memfermentasi plat mannitol salt agar, sel berbentuk bulat bergerombol, bersifat Gram +, memfermentasi maltosa dan laktosa, mengkoagulasi plasma kelinci dan bereaksi positif terhadap uji clumping faktor dan Voges Proskouer. Pada penelitian ini, hasil uji terhadap kitosan cangkang bekicot pada kosentrasi 300-700 ppm adalah sensitif. Penelitian ini dapat disimpulkan bahwa penderita ulkus diabetikum yang diidentifikasi adalah Staphylococcus aureus. Isolat S. aureus sebagian besar sensitif terhadap kitosan cangkang bekicot (Achatina fulica).
\end{abstract}

Kata kunci:Staphylococcus aureus, Ulkus Diabetikum, Kitosan Cangkang Bekicot (Achatina fulica).

\begin{abstract}
One of the bacteria that causes diabetic ulcers is Staphylococcus aureus. Inappropriate use of antibiotics results in the emergence of antibiotic resistant $S$. aureus or survival due to genetic changes. The natural material that has antibacterial properties is gastropod shell chitosan (Achatina fulica). This study aims to isolate and antibacterial test of gastropod shell chitosan against Staphylococcus aureus from diabetic ulcer. In this study, it was carried out correctly experimental S. aureuswas isolated from diabetic ulcer patients and identified based on culture properties, Gram staining, biochemical tests and confectionery tests. The isolates were then tested for sensitivity to snail shell chitosan. The results showed that the isolation of bacteria that grew and could ferment the mannitol salt agar plate, clustered round cells, Gram +, ferment maltose and lactose, coagulase rabbit plasma and react positively to the clumping factor test and Voges Proskouer. In this study, the test results on gastropod shell chitosan (Achatina fulica) at a concentration of 300-700 ppm were sensitive. This study concluded that patients with diabetic ulcers identified were Staphylococcus aureus. S. aureus isolates are mostly sensitive to gastropod shell chitosan (Achatina fulica).
\end{abstract}

Keywords: Staphylococcus aureus, Diabetic ulcer, Gastropod Shell Chitosan (Achatina fulica).

\section{PENDAHULUAN}

Penderita diabetes mellitus, hiperglikemia dapat meningkatkan risiko komplikasi mikrovaskular dan makrovaskular, sehingga dapat meningkatkan risiko komplikasi yang lebih jauh, seperti retinopati, penyakit kardiovaskular, nefropati, dan neuropati perifer yang dapat 
mengakibatkan ulkus diabetikum (International Diabetes Federation, 2017). Salah satu bakteri penyebab ulkus diabetikum adalah Staphylococcus aureus.Oleh karena itu untuk mengobati tersebut dengan menggunakan antibiotik.Pengunaan antibiotik yang tidak tepat menyebabkan munculnya $S$. aureusyang resisten terhadap antibiotik atau bertahan hidup karena adanya perubahan genetik. S.aureus tergolong resisten terhadap sefotaksim, seftriakson, siprofloksasin (Hatanta, 2013). Oleh karena itu, perlu dicari alternatif lain dengan pemanfaatan sumber biomaterial bahan alam, karena penggunaan bahan alami relatif lebih dapat diterima tubuh dibandingkan dengan bahan-bahan sintesis.Salah satu bahan yang belum dimanfaatkan dengan optimal adalah kitosan dari cangkang bekicot. Penelitian tentang efektivitas kitosan sebagai antibakteri juga dilakukan oleh Goy et al (2015) menyatakan bahwa kitosan rajungan mampu menghambat pertumbuhan bakteri S. aureusdan E. coli pada konsentrasi 1000-1500 ppm. Komariah (2014) bahwa pemanfaatan ekstrak kitosan cangkang udang dan rajungan mampu menghambat pertumbuhan S. aureuspada konsentrasi $22,5 \%$ 90\%. Menurut Islam et al., (2011) menunjukkan pemanfaatan ekstrak kitosan cangkang kepiting mampu menghambat pertumbuhan S. aureusdan E. coli pada konsentrasi 600-1000 ppm.

Kitosan merupakan senyawa organik turunan kitin yang berasal dari biomaterial kitin (Holipah dkk,. 2010). Kitosan adalah senyawa organik turunan kitin, berasal dari biomaterial kitin yang banyak dimanfaatkan untuk berbagai keperluan (Holipah dkk, 2010). Kitosan memiliki kelebihan yakni tidak beracun, mudah mengalami biodegradasi dan bersifat polielektrolitik (Hastuti dan Hadi, 2009). Kitin dan kitosan secara morfologi berupa padatan putih, tidak beracun, tidak berbau, dan bersifat sebagai antibakteri (Gomes et al., 2014; Mohan et al., 2012). Kitosan juga memiliki sifat serbaguna yang dapat digunakan di berbagai bidang baik biomedis (Jayakumar et al., 2010), rekayasa jaringan (Shavandi et al., 2015), tekstil (Demarchi et al., 2013; Chandrasekar et al., 2014), dan industri pengolahan makanan (Bae et al., 2013). Kitosan memiliki kemampuan sebagai antibakteri dan antijamur, seperti yang telah dibuktikan dalam beberapa penelitian sebelumnya.Sehingga potensikitosan untuk dijadikan sebagai antibakteriS. Aureus dari penderita ulkus diabetikum, dengan pertimbangan kitosan mengandung enzim lisosim dan gugus amino polisakarida yang dapat menghambat pertumbuhan bakteri (Rismana, 2010). Mekanisme antibakteri yang mungkin terjadi yaitu molekul kitosan memiliki kemampuan untuk berinteraksi dengan senyawa pada permukaan sel bakteri kemudian teradsorbsi membentuk semacam layer (lapisan) yang menghambat 
saluran transportasi sel sehingga sel mengalami kekurangan substansi untuk berkembang dan mengakibatkan matinya sel bakteri tersebut.

\section{METODE PENELITIAN}

Jeni penelitian ini adalah true eksperimen dengan rancangan post test only control group design. Bahan-bahan yang diperlukan dalam penelitian ini adalah cangkang bekicot (Achatina fulica F), bakteri Staphylococcus aureus yang berasal dari isolasi ulkus diabetikum, Mueller-Hinton Agar (Oxoid), $\mathrm{NaCl}$ fisiologis, aquades, pepton 10\% (Oxoid), paper disc (Oxoid), $\mathrm{NaOH}, \mathrm{HCl}, \mathrm{NaOCl}$, dan antibiotika ampisilin dalam bentuk kertas cakram tunggal. Alat yang digunnakan pada penelitian ini adalah jarum ose, labu spiritus, pengaduk magnetic stirer, laminar air flow, autoklaf, oven, cawan petri, tabung reaksi, inkubator, vortex, serta alat gelas lainnya (presisi dan non presisi), swab, dan petridis.

\section{Isolasi kitosan cangakang bekicot}

Cangkang bekicot dilakukan dengan cara dicuci dengan air hingga bersih, kemudian dikeringkan di bawah sinar matahari. Cangkang bekicot yang telah bersih dihaluskan untuk mendapatkan ukuran sebesar 100 mesh. Kemudian ditimbang cangkang bekicot sebesar 100 gram. Selanjutnya pemurnian kitin dengan cara deproteinasi ke dalam labu alas bulat $250 \mathrm{ml}$ yang berisi serbuk cangkang bekicot ditambahkan larutan $\mathrm{NaOH} \mathrm{3,5 \%} \mathrm{dengan} \mathrm{perbandingan}$ 10:1 (v/b), kemudian dipanaskan sambil diaduk dengan pengaduk magnetik selama 2 jam pada temperatur $65^{\circ} \mathrm{C}$. Setelah dingin, disaring dan dinetralkan dengan aquades. Padatan yang diperoleh dikeringkan dalam oven $60^{\circ} \mathrm{C}$ hingga kering.

Tahap kedua demineralisasi yaitu serbuk cangkang bekicot hasil deproteinasi ditambah larutan $\mathrm{HCl} 1 \mathrm{~N}$ dengan perbandingan 15:1 (v/b) dalam labu alas bulat $500 \mathrm{ml}$ dan direfluks pada suhu $40^{\circ} \mathrm{C}$ selama 30 menit, kemudian didinginkan. Setelah dingin, disaring dan padatan dinetralkan dengan aquades, kemudian dikeringkan dalam oven $60^{\circ} \mathrm{C}$. Tahap ketiga depigmentasi yaitu larutan $\mathrm{NaOCl}$ 0,315\% ditambahkan kedalam serbuk hasil demineralisasi dengan perbandingan 10:1 (v/b) dalam labu alas bulat $250 \mathrm{ml}$. Refluks dilakukan selama 1 jam pada suhu $40^{\circ} \mathrm{C}$, kemudian padatan disaring dan dinetralkan dengan aquades. Padatan hasil penetralan dikeringkan pada oven pada suhu $80^{\circ} \mathrm{C}$ sampai berat tetap (Kusumaningsih, dkk., 2004). 
Isolasi kitosan cangkang bekicot dilakukan melalui proses destilasi kitin dengan menambahkan $\mathrm{NaOH}$ 60\% dengan perbandingan 20:1 (v/b) dan merefluksnya pada suhu 100$140^{\circ} \mathrm{C}$ selama 1 jam. Setelah dingin disaring dan padatan yang diperoleh dinetralkan dengan akuades. Padatan kemudian dikeringkan dalam oven pada suhu $80^{\circ} \mathrm{C}$ selama 24 jam dan kitosan cangkang bekicotdianalisis mutunya yaitu warna, kelarutan, dan kadar air.

\section{Pengenceran Kosentrasi Kitosan Cangkang bekicot}

Pembuatan kosentrasi kitosan cangkang bekicot dibuat baku induk1000 ppm dengan cara menimbang $500 \mathrm{mg}$ kitosan cangkang bekicot, dimasukkan labu ukur $500 \mathrm{ml}$, kemudian ditambahkan asam asetat $1 \%$ sampai tanda batas dan dikocok sampai homogen. Untuk pembuatan baku seri dari baku induk pada kosentrasi 300 ppm dengan cara pipet baku induk $15 \mathrm{ml}$ dan dimasukkan labu ukur $50 \mathrm{ml}$, dan tambahkan asam acetat $1 \%$ sampai tanda batas.Serta dikocok sampai homogen.Sedangkan pada kosentrasi 400, 500, 600 dan 700 seperti langkah pada kosentrai 300 ppm.

\section{Isolasi $S$. aureus asal penderita ulkus diabetikum}

Spesimen akan diambil dari swab pada ulkus diabetikum di Rumah Sakit Gambiran Jawa Timur. Pengambilan spesiemen swab pada ulkus akan dilakukan dengan cara membuat apusan, pada pasien diberi penjelasan mengenai tindakan yang akan dilakukan, pengambilan ulkus pasien dengan menggunakan swab steril pada bagian ulkus diabetikun dengan cara memutar seluruh bagian swab steril yang sudah dicelupkan nutrient broth. Lalu swap steril akan dimasukan ke dalam tabung steril. Tabung yang berisi swab dari ulkus tersebut diberi label dan dimasukkan ke dalam kotak dan segera dibawa ke laboratorium mikrobiologi. Kemudian spesimen akan dibiakan pada media Nutriet Agar (NA). Setelah itu bakteri yang dibiakan tumbuh pada media tersebutdan dilakukan pewarnaan Gram untuk menentukan jenis bakteri Gram positif dan Gram negatif. Setelah diketahui jenis bakteri dari pewarnaan Gram poistif karena pada penelitian ini menggunakan bakteri Gram positif maka langsung ditanam pada media blood agar dan dites biokimiawi. Bakteri Gram positif akan dilakuan dengan menggunakan uji glukosa, uji katalase dan tes DNAse.

Pengujian katalase ini dilakukan dengan meneteskan cairan hidrogen peroksida $\left(\mathrm{H}_{2} \mathrm{O}_{2}\right)$ pada kaca objek yang bersih. Kemudiankoloni diambil dari media blood agar sebanyak satu ose dan dioleskan pada kaca objek yang sudah terdapat $\mathrm{H}_{2} \mathrm{O}_{2}$. Hasil positif jikaterdapat gelembung udara yang menandakan Staphylococcus sp. dan hasil negatif apabila tidak terlihat gelembung udarapada objek gelas (Leboffe \& Pierce 2011).Selanjutnya uji Mannitol 
Salt Agar (MSA). Pengujian ini pada media MSA dilakukan untuk mengidentifikasi dari bakteri Staphylococcussp yang pathogen/tidak. Kultur bakteri dari media blood agar ditanam pada media MSA kemudian diinkubasi pada inkubator dengan suhu $35^{\circ} \mathrm{C}$ selama $18-72$ jam. S. aureus merupakan bakteri yang memfermentasi mannitol akan membentuk koloni berwarna kuning dengan zona kuning pada media. Sedangkan bakteri yang tidak memfermentasi manitol seperti $S$. epidermidis membentuk koloni berwarna merah muda hingga merah tanpa adanya perubahan warna kuning pada media MSA (Jawetz et al., 2001; Katetee et al, 2010).

Uji DNAse Udigunakan untuk melihat aktivitas deoksiribonuklease dan koagulase positif pada bakteri. Bakteri yang telah dikultur akan diinokulasi pada DNAse agar plate, lalu diinkubasi pada suhu $37^{\circ} \mathrm{C}$ selama 24 jam. Jika pertumbuhan bakteri kurang baik, maka waktu untukinkubasi ditambah 24 jam. Setelah diinkubasi, agarplate digenangi dengan $\mathrm{HCl} 1$ M selama 5 menit. Hasil yangpositif apabila ditemukan zona bening disekitar koloni yang menandakan terdapat akitivitas DNAse yang menghidrolisis deoksiribonuklease.Bakteri yang mempunyai aktivitas DNAse positif antara salah satunya adalah $S$. aureus (Jawetz et al., 2001; Katetee et al, 2010).

\section{Uji Antibakteri Kitosan Cangkang Bekicot}

Uji antibakteri dilakukan dengan cara uji difusi Kirby Bauerdengan menggunakan media Muller Hinton Agar (MHA).MHA ditimbang sebanyak 6,8 gram dan dicampur dengan aquades sebanyak $200 \mathrm{ml}$ dalam tabung Erlenmeyer kemudian panaskan sampai larut dan disterilkan dalam autoklaf selama 15 menit pada suhu $121^{\circ} \mathrm{C}$. Media Mueller Hinton Agar (MHA) dituang ke dalam cawan petri sebanyak $25 \mathrm{ml}$ perpetri. Koloni bakteri Staphylococcus aureusmurni berasal dari ulkus diabetikum diambil dengan jarum ose steril, lalu ditanamkan pada media agar miring dengan cara menggores.

Bakteri yang telah digores pada media agar diinkubasi dalam inkubator pada suhu $37^{\circ} \mathrm{C}$ selama 24 jam. Bakteri yang telah diinkubasi diambi koloninya dari media agar miring dengan menggunakan jarum ose steril kemudian dimasukkan ke dalam media $\mathrm{NaCl}$ Broth sampai kekeruhannya sama dengan standar McFarland. Larutan standar McFarland 0,5 ekuivalen dengan suspensi sel bakteri dengan konsentrasi 1,5 x $108 \mathrm{CFU} / \mathrm{ml}$. Kekeruhan ini yang dipakai sebagai standar suspensi bakteri uji. 
Uji aktivitas kitosan cangkang bekicot (Achatina fulica) terhadap pertumbuhan bakteri S. aureus asal penderita ulkus diabetikum. Diinokulasikan dengan cara swab steril dicelupkan ke dalam inokulum, kurangi inokulum berlebih dengan cara menekan dan memutar swab kuat-kuat pada sisi tabung. Diusapkan swab keseluruh permukaan media, usapkan juga lidi kapas ke sekeliling pinggiran permukaan agar. Plate setelah ditanami dibiarkan beberapa menit pada temperatur kamar dalam keadaan tertutup.Perendaman disk kedalam masingmasing konsentrasi kitosan cangkang bekicot selama 10 menit dan ambil paperdisk dengan menggunakan pinset steril. Cakram kertas yang berisi masing-masing pengenceran kitosan cangkang bekicot diletakkan pada media MHA yang telah diinokulasi, menggunakan pinset steril. Kemudian media diletakkan pada incubator pada suhu $37^{\circ} \mathrm{C}$ selama $24 \mathrm{jam}$. Diamater zona diukur dengan jangka sorong dan dicatat dalam mm, kemudian hasil yang di dapat diinterpretasikan dengan cara mengukur zona jernih disekitar paper disk. Data yang telah diperoleh dilakukan perhitungan dan dianalisis secara desktiptif.

\section{HASIL DAN PEMBAHASAN}

\section{Isolasi Kitosan Cangkang Bekicot (Achatina fulica)}

Proses isolasi kitosan diawali dengan proses isolasi kitin dari cangkang bekicot. Isolasi kitosan dilakukan dengan tiga tahapan yaitu deproteinasi, demineralisasi, dan depigmentasi. Menurut Kusumaningsih dkk., (2014) deproteinasi dengan $\mathrm{NaOH}$ 3,5\% bertujuan untuk menghilangkan protein. Tahap demineralisasi Demineralisasi yaitu hasil deproteinasi berupa padatan kering dengan menggunakan larutan HCL $1 \mathrm{~N}$ dengan perbandingan $15: 1(\mathrm{v} / \mathrm{b})$ selama 30 menit dengan suhu $40^{\circ} \mathrm{C}$.

Proses ini bertujuan untuk menghilangkan garam-garam organik atau kandungan mineral yang ada pada crude kitin cangkang bekicot. Kandungan mineral utamanya adalah $\mathrm{CaCo}_{3}$ dan $\mathrm{Ca}_{3}\left(\mathrm{PO}_{4}\right)_{2}$, senyawa tersebut akan bereaksi dengan asam klorida menghasilkan kalsium klorida yang larut dalam air. Proses pemisahan ditunjukkan dengan terbentuknya gas $\mathrm{CO}_{2}$ berupa gelembung udara saat larutan HCL ditambahkan dalam serbuk cangkang bekicot hasil deproteinasi.

Hasil tahapan demineralisasi berupa crude kitin dilakukan pembilasan dengan aquadest sampai $\mathrm{pH} \mathrm{7,} \mathrm{pembilasan} \mathrm{tersebut} \mathrm{bertujuan} \mathrm{untuk} \mathrm{menghilangkan} \mathrm{sisa-sisa} \mathrm{HCl}$ yang terdapat pada kitin, agar kitin tidak rusak ketika direaksikan dengan $\mathrm{NaOCl}$ pada tahap 
depigmentasi karena perubahan $\mathrm{pH}$. Serbuk yang telah dibilas kemudian dikeringkan menggunakan oven dengan suhu $60^{\circ} \mathrm{C}$, diperoleh hasil rendemen demineralisasi sebesar $0,87 \%$. Rendemen yang diperoleh dari proses depigmentasi adalah $0,85 \%$ dan total kitin ratarata 21,33 gram dari serbuk cangkang bekicot. Proses deasetilasi terjadi pemutusan ikatan antara kation dengan nitrogen pada gugus asetil kitin menjadi gugus amino.

Derajat deasetilasi merupakan suatu parameter mutu yang menunjukkan gugus asetil yang dapat dihilangkan dari kitin. Deasetilasi yang dihasilkan sebanyak 21,3 gram yang sudah menjadi kitosan. Hasil berat setiap tahapan isolasi kitosan cangkang bekicot yang terlihat pada Tabel 1.

Tabel 1. Berat Tahapan Isolasi Kitosan Cangkang Bekicot (Achatina fulica F.)

\begin{tabular}{cccc}
\hline No. & Parameter & Massa $(\mathrm{gr})$ & $\%$ Perolehan \\
\hline 1. & Deproteinasi & $23,61 \mathrm{gr}$ & $0,94 \%$ \\
2. & Demineralisasi & $21,92 \mathrm{gr}$ & $0,87 \%$ \\
3. & Depigmentasi & $21,33 \mathrm{gr}$ & $0,85 \%$ \\
4. & Deasetilasi & $21,23 \mathrm{gr}$ & $0,84 \%$ \\
\hline
\end{tabular}

Pada Tabel 1. menunjukkan bahwa diperoleh deproteinasi sebanyak 0,94\%; demineralisasi sebanyak $0,87 \%$; depigmentasi sebanyak 0,85\%; dan kitosan diperoleh sebanyak $0,84 \%$ dari 25 gram serbuk cangkang bekicot. Mutu kitosan cangkang bekicot yang diperoleh pada penelitian ini secara morfologi berwarna putih, tidak larut dalam air akan tetapi larut dalam asam asetat, kadar air $\leq 10 \%$. Kitosan bersifat higroskopis sehingga mudah menyerap uap air dari udara disekitarnya.

Kadar air yang terkandung didalam kitosan dinyatakan sebagai $\mathrm{H}_{2} \mathrm{O}$ yang terikat pada gugus-gugus fungsional polimer kitosan, terutama gugus amina, asetil dan hidroksil melalui ikatan hydrogen. Kadar air kitosan bergantung pada kelembaban relatif udara sekeliling tempat penyimpanan karena kitosan bersifat higroskopis.

Hasil uji kadar air kitosan cangkang bekicot (A. fulica) pada penelitian ini lebih kecil jika dibandingkan dengan standar mutu kitosan, maka kadar air kitosan cangkang bekicot $(A$. fulica) telah sesuai dengan standar mutu kitosan yang ditetapkan (Dompeipen dkk., 2016). Kitosan cangkang bekicot yang telah memenuhi standart mutu dilanjutkan dengan pengujian terhadap bakteri S. aureus yang berasal dari penderita ulkus diabetikum. 


\section{Isolasi S. aureus yang Berasal dari Penderita Ulkus Diabetikum.}

S. aureus pada media Mannitol Salt Agar (MSA) menunjukkan pertumbuhan koloni berwarna putih kekuningan dikelilingi zona kuning karena kemampuan memfermentasi mannitol. Zona kuning menunjukkan adanya fermentasi mannitol, yaitu asam yang dihasilkan, menyebabkan perubahan phenol red pada agar yang berubah dari merah menjadi berwarna kuning (Austin, 2010). Hasil dari pewarnaan Gram adalah Gram positif, berbentuk kokus tersusun dalam kelompok-kelompok tidak teratur (menyerupai buah anggur), dapat pula tersusun empat-empat (tetrad), membentuk rantai (3-4 sel), berpasangan atau satu-satu. Pelezar (1988) menyatakan dinding sel bakteri Gram positif pada umumnya memiliki struktur dinding sel yang tebal (15-80 nm) dan sedikit lemak (1-4\%). Dinding sel bakteri Gram positif memiliki peptidoglikan yang lebih banyak dan mampu mempertahankan zat warna unggu sehingga warna ungu yang muncul pada pengamatan diperoleh dengan hasil kontras. Hasil uji fetanol manitol dan uji pewarnaan Gram dapat dilihat pada Gambar tersaji dibawah ini.
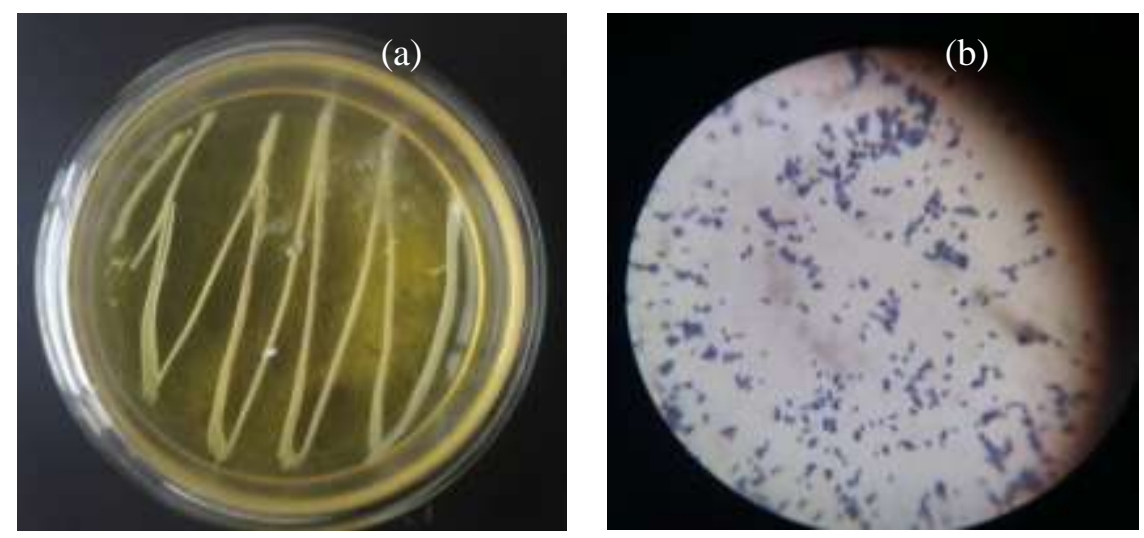

Gambar 1. Hasil uji Bakteri: (a). fermentasi mannitol agar, dan (b). pewarnaan Gram

Hasil pewarnaan Gram dapat diketahui semua perlakuan bakteri Gram positif. Tahap selanjutnya adalah dengan melakukan uji katalase yang digunnakan untuk membedakan spesies Staphyloccous sp. dan Streptococcus. Katalase positif ditunjukkan adanya gelembung gas yang diproduksi oleh genus Staphyloccous sp. Hasil uji katalase pada penelitian ini menunjukkan hasil positif $S$. aureus dari pasien ulkus diabetikum. Hal ini dikarenakan menghasilkan enzim katalase mampu menghidrolisis hydrogen peroksida $\left(\mathrm{H}_{2} \mathrm{O}_{2}\right)$ menjadi air $\left(\mathrm{H}_{2} \mathrm{O}\right)$ dan gelembuang gas $\left(\mathrm{O}_{2}\right)$ (Yurdakul et al,. 2013). Uji koagulase digunnakan untuk mengetahui ada tidaknya enzim koagulase yang dihasilkan Staphyloccous sp. Hasil positif jika terdapat gumpalan pada tabung. Hasil yang diperoleh pada penelitian ini adalah positif semua dihasilkan oleh $S$. aureus. 


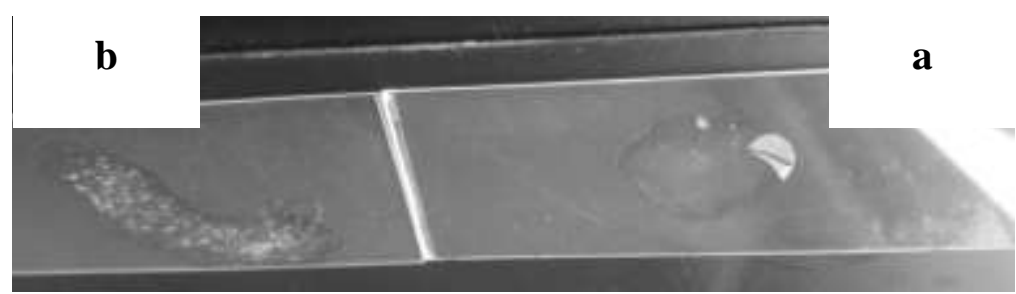

Gambar 2. a) uji koagulase; b) uji katalase

Pada Gambar 2. diatas menunjukkan hasil uji katalase dan koagulase terhadap sampel yang diujikan yang tumbuh pada MSA didapatkan, bahwa isolat $S$. aureus menunjukkan reaksi positif. Berdasarkan uji gula-gula laktosa dan maltosa menunjukkan bahwa hasil positif terhadap laktosa dan hasil positif terhadap maltosa. Uji ini digunakan untuk mengetahui kemampuan bakteri dalam menfermentasi karbohidrat. Berdasarkan penelitian tersebut dapat disimpulkan bahwa pada ulkus diabetikum bakteri yang telah diisolasi dan identifikasi adalah S. aureus.

\section{Uji Antibakteri Kitosan Cangkang Bekicot}

Pengujian antibakteri $S$. aureus dengan berbagai kosentrasi kitosan cangkang bekicot dilakukan selama 1 hari (24 jam) terhadap bakteri S. aureus pada ulkus diabetikum. Adapun zona hambat yang dihasilkan seperti terlihat terlihat pada Tabel 2 berikut ini.

Tabel 2. Hasil Uji Aktivitas Kitosan Cangkang Bekicot Terhadap Pertumbuhan Bakteri S.aureus Pada Ulkus Diabetikum.

\begin{tabular}{ccc}
\hline No & Perlakuan & $\begin{array}{c}\text { Rata-rata Diameter Zona Hambat } \\
\text { Pertumbuhan Bakteri (mm) }\end{array}$ \\
\hline 1 & $300 \mathrm{ppm}$ & 20.16 \\
2 & $400 \mathrm{ppm}$ & 24.33 \\
3 & $500 \mathrm{ppm}$ & 35.38 \\
4 & $600 \mathrm{ppm}$ & 36.37 \\
5 & $700 \mathrm{ppm}$ & 36.87 \\
6 & Kontrol (+) & 8.00 \\
7 & Kontrol (-) & 6.00 \\
\hline Keterangan : & 300 ppm-700 ppm : kosentrasi kitosan cangkang bekicot; Kontrol (+) : ampisilin; Kontrol (-) : \\
\multicolumn{2}{c}{ aquadest steril. }
\end{tabular}

Pada Tabel 2 terlihat bahwa zona hambat terbesar terdapat pada konsentrasi 700 ppm dan terendah pada konsentrasi 300 ppm. Daya hambat kitosan cangkang bekicot pada berbagai konsentrasi lebih tinggi dibanding kontrol (+) dan kontrol (-). Hal ini disebabkan kitosan cangkang bekicot mampu menghambat bakteri S. aureus berasal dari penderita ulkus diabetikum. Kitosan dari cangkang bekicot diduga mampu menghambat dan membunuh 
pertumbuhan bakteri $S$. aureus pada ulkus diabetikum (bakterisid). Bakterisid adalah sifat antibiotik yang dapat membunuh bakteri (Mims et al., 2004). Menurut Liu et al., (2004) kitosan memiliki aktivitas antibakteri dengan cara membunuh bakteri dan merusak membran sel bakteri. Kitosan mengandung enzim lisozim dan gugus aminopolysacarida yang dapat menghambat pertumbuhan bakteri S. aureus. Enzim lisozim merupakan enzim yang sanggup mencerna dinding sel bakteri sehingga bakteri akan kehilangan kemampuannya menimbulkan penyakit dalam tubuh (hilangnya dinding sel ini menyebabkan sel bekteri akan mati).

Menurut Wardaniati dan Setyaningsih (2009) menyatakan bahwa kitosan mengandung enzim lysosim dan gugus aminopolysacharida yang dapat menghambat pertumbuhan bakteri dan efisiensi daya hambat kitosan terhadap bakteri. Kemampuan dalam menekan pertumbuhan bakteri disebabkan kitosan memiliki polikation bermuatan positif yang mampu menghambat pertumbuhan bakteri (Riski dan Sami, 2015).

Salah satu mekanisme yang mungkin terjadi yaitu molekul kitosan memiliki kemampuan untuk berinteraksi dengan senyawa pada permukaan sel bakteri S. aureus kemudian teradsorbsi membentuk semacam layer (lapisan) yang menghambat saluran transportasi sel sehingga sel mengalami kekurangan substansi untuk berkembang biak dan mengakibatkan matinya sel bakteri S.aureus dari penderita ulkus diabetikum (Azora et al., 2013). Oleh karna itu pasien yang memiliki ulkus diabetikum lebih baik memakai bahan biomaterial berasal dari kitosan cangkang bekicot yang dapat dijadikan terobosan untuk menyembuhkan luka akibat karena bakteri S. aureus. Hal ini dikarenakan kitosan cangkang bekicot bersifat sebagai antibakteri.

\section{KESIMPULAN}

Berdasarkan uraian diatas dapat disimpulkan bahwa isolasi bakteri S. aureus dari pasien ulkus diabetikum memiliki karakteristik fisiologis yaitu dapat memfermentasi plat mannitol salt agar ditandai perubahan warna menajdi kuning, sel berbentuk bulat bergerombol, bersifat Gram (+), memfermentasi maltosa dan laktosa, mengkoagulase plasma kelinci dan bereaksi positif terhadap uji Clumping Factor dan Voges Proskouer. Hasil identifikasi benar-benar $S$. aureus. Kitosan cangkang bekicot bersifat sebagai antibakteri terhadap S. aureus. 


\section{UCAPAN TERIMAKASIH}

Terimakasih disampaikan kepada LLDIKTI Wilayah VII yang telah mendanai penelitian dosen pemula tahun 2019 dengan nomor kontrak 063/AKFARSBY/LPPM/70.30/III/2019.

\section{REFERENSI}

Austin, T.X. 2010. Manitol Salt Agar. Austin Community College District. http:// www.austincc.edu/microbugz/html/mannitol_s alt_agar.html. [22-03-10].

Azora, G. M., Suwondo dan Febrita, E., Efektivitas Chitosan Kulit Udang Terhadap Nilai Gizi Tahu Sebagai Sumber Belajar Biologi dengan Model Pembelajaran DI(Direct Intruction) Pada Konsep Bioteknologi. Repository. Available as PDF File; p.2.

Bae, M. J., Shin, H. S., Kim, E. K., Kim, J. \& Shon, D. H., 2013. Oral Administration Of Chitin And Chitosan Prevents Peanut-Induced Anaphylaxis In A Murine Food Allergy Model. International Journal of Biological Macromolecules, 61 (3): 164 168. doi: 10.1016/j.ijbiomac.2013.06.017

Chandrasekar, S., Vijayakumar, S. \& Rajendran, R., 2014. Application of chitosan and herbal nanocomposites to develop antibacterial medical textile. Biomedicine and Aging Pathology, 4(1): 59 - 64. Doi : 10.1016/j.biomag.2013.10.007

Dompeipen, E. J., Kaimudin, M., \& Dewa, R, P., 2016. Isolasi Kitin Dan Kitosan Dari Limbah Kulit Udang. Majalah Biam. 12 (1): 32-38.

Demarchi, C., Campos, M., \& Rodrigues, C. A., 2013. Adsorption Of Textile Dye Reactive Red 120 By The Chitosan-Fe(III)-Crosslinked: Batch and Fixed-Bed Studies. Journal of Environmental Chemical Engineering, 1(4): 1350 - 1358. DOI: $10.1016 /$ j.jece.2013.10.005

Gomes, J. R. B., Jorge, M., \& Gomes, P., 2014. Interaction of chitosan and chitin with Ni, Cu and $\mathrm{Zn}$ ions : A computational study. Journal of Chemical Thermodynamics, 73 (5): 121 - 129. DOI: 10.1016/j.jct.2013.11.016

Goy, R. C., Morais, S. T. B., \& Assis, O. B. G., 2015. Evaluation of antimicrobial activity of chitosan and its quaternized derivative on Escherichia coli and Staphylococcus aureus Growth. Revista Brasileira de Farmacognosia 26(4): 122-127. http://dx.doi.org/10.1016/j.bjp.2015.09.010

Hastuti, B., \& Hadi, S., 2009. Pemanfaatan Chitosan dari Limbah Udang sebagai Bahan Pengawet Alami untuk Memperlama Daya Simpan Pada Makanan. Prosiding Seminar Nasional Kimia dan Pendidikan Kimia.

Hatanta, A., 2013. Kajian Penggunaan Antibiotik Pada Pasien Infeksi Ulkus Kaki Diabetik IRNA PD RSUP Dr. M. Djamil Padang. [Thesis]. Program Pascasarjana, Universitas Andalas. Padang.

Holipah, S. N., Wijayanti, E., \& Saputra, V., 2010. Aplikasi Kitosan Sebagai Pengawet Alami dalam Meningkatkan Mutu Simpan Produk Pasca Panen. Program Kreativitas Mahasiswa, Institut Pertanian Bogor. Bogor. 
International Diabetes Federation. 2017. IDF Diabetes Atlas Seventh Edition 2017. Dunia: IDF.

Islam, M. M., Masum, S. M., Mahbub, K. R., \& Haque, M. Z., 2011. Antibacterial Activity of Crab-Chitosan Against Staphylococcus aureus and Escherichia coli. Journal of Advanced Scientific Research, 2(4): 63-66.

Jayakumar, R., Prabaharan, M., Nair, S. V. \& Tamura, H. 2010. Novel chitin and chitosan nanofibers in biomedical applications. Biotechnology Advances, 28 (1): 142 - 150. https://doi.org/10.1016/j.biotechadv.2009.11.001

Jawetz, E, Melnick, J. L, \& Adelberg, E.A, 2001. Mikrobiologi Kedokteran. Edisi Pertama. Salemba Medika. Jakarta.

Kateete, D. P., Kimani, C. N., Katabaz, F. A., Okeng, A., Okee, M. S,, Nanteza, A., Joloba, M.L., \& Najjuka, F. C., 2010. Identification of Staphylococcus aureus: DNase and Mannitol salt agar improve the efficiency of the tube coagulase test. Annals of Clinical Microbiology and Antimicrobials. Vol. 9: (23): 1-7. DOI: 10.1186/14760711-9-23

Kusumaningsih, T., Masykur, A., \& Arief, U., 2004. Pembuatan Kitosan dari Kitin Cangkang Bekicot (Achatina fulica). Jurnal Biofarmasi, 2 (2), 64-68.

Komariah, A., 2014. Efektivitas Antibakteri Nano Kitosan Terhadap Pertumbuhan Staphylococcus aureus (In Vitro). Proceeding Biology Education Conference. 11(1):371-377.

Leboffe, M.J., \& Pierce, B. E., 2011. A Pthographic Atlas for the Microbiology Laboratory. 4th Edition. Morton Publishing Company. Englewood, Colorado. pp.207-217.

Liu, H., Du, Y., Wang, X., \& Sun, L., 2004. Chitosan kills bacteria through cell membrane damage. International Journal of Food Microbiology. Vol 95(2): 147-155. doi:10.1016/j.ijfoodmicro.2004.01.022

Mims, C., Dockrell, H.M., Goring, R.V., Roitt, I., Wakelin, D., Zuckerman, M., 2004. Medical Microbiology 3rd Edition. Mosby, Edinburgh, UK, p. 648. ISBN $9780723432593 \mathrm{https} / / /$ researchonline.lshtm.ac.uk/id/eprint/14346

Mohan, C. O., Ravishankar, C. N., Lalitha, K. V. \& Gopal, T. K. S., 2012. Effect of chitosan edible coating on the quality of double filleted Indian oil sardine (Sardinella longiceps) during chilled storage. Food Hydrocolloids, 26 (1): 167 - 174. DOI: 10.1016/j.foodhyd.2011.05.005

Pelczar, M. J., dan Chan, E. C. S., 1988, Dasar-Dasar Mikrobiologi, diterjemahkan oleh Hadioetomo, R. S., Penerbit Universitas Indonesia, Jakarta.

Rismana, E., 2010. Pengembangan Formulasi Sediaan Topikal Wound Healing Menggunakan Bahan Aktif Kitosan dan Ekstrak Pegagan, Pusat Teknologi Farmasi Dan Medika Deputi Bidang TAB - BPPT, Jakarta.

Riski, R., dan Sami F. J., 2015. Formulasi Krim Anti Jerawat Dari Nanopartikel Kitosan Cangkang Udang Windu (Penaeusmonodon). JF FIK UINAM, Vol. 3 (4). 1-15

Shavandi, A., Bekhit, A. E.-D. A., Ali, M. A., Sun, Z. \& Gould, M., 2015. Development and characterization of hydroxyapatite/ $\beta$-TCP/chitosan composites for tissue engineering applications. Materials Science and Engineering: C, 56: $481-493$. 
Wardaniati, R.A. dan Setyaningsih, S., 2009. Pembuatan Chitosan dari Kulit Udang dan Aplikasinya untuk Pengawetan Bakso. Makalah Penelitian, UNDIP. http://eprints.undip.ac.id/1718/1/makalah_penelitian_fix.pdf

Yurdakul, N. E., Erginkaya, Z., \& Unal, E., 2013. Antibiotic Resistence of Enterococci, Coagulase, Negative Staphylococci and Staphylococcus aureus Isolated from Chicken Meat. Czech J. Food Sci. 31 (1): 14-19. 